\title{
THE FATE OF PENICILLIN-DAMAGED ENTEROCOCCI IN THE MOUSE KIDNEY
}

\author{
P. J. WATT \\ Wright-Fleming Institute, St Mary's Hospital Medical School, London
}

GuZE AND Kalmanson (1964) reported that after rats suffering from enterococcal pyelonephritis had been treated with penicillin, larger numbers of bacteria were recovered from portions of their kidneys processed and cultured on media containing $0.3 \mathrm{M}$ sucrose than from portions cultured on standard media. Presumably the difference in viable counts was due to the presence in the kidneys of many damaged, osmotically fragile, but still viable organisms. These forms, termed "protoplasts", were recovered from the renal cortex as well as from the medulla, and survived when the kidney was made hypotonic with an osmotic diuretic (Kalmanson and Guze, 1964). However, the authors did not demonstrate the recovery of protoplasts growing as L-forms and it remains to be established that the enterococci surviving in the kidneys after treatment with penicillin are in fact variant forms lacking a rigid cell wall.

This paper reports attempts to induce the formation of " protoplasts", or L-forms, by administering penicillin to mice suffering from experimental enterococcal pyelonephritis, and to recover these forms in culture from the kidneys and urine. To test the hypothesis that even though the renal milieu may support the growth of enterococcal L-forms, penicillin-damaged enterococci may be destroyed by defence systems in the kidney, comparative observations were made in immunologically normal mice and mice receiving cortisone treatment (see also Watt, 1969).

\section{MATERIALS AND METHODS}

Enterococci and infection of mice

Strains of Streptococcus faecalis included strain B, which was isolated from a patient with endocarditis, and strains $M, R, T$ and $Y$, which were recovered from patients with urinary infections. To test the ability of the strains to induce pyelonephritis the enterococci were injected intravenously into mice and recovered from the kidneys $72 \mathrm{hr}$ after challenge. After a second passage the kidneys were removed aseptically and emulsified in $10 \mathrm{ml}$ of 16 per cent. ( $\mathrm{v} / \mathrm{v})$ glycerol broth and stored at $-20^{\circ} \mathrm{C}$ (Gore and Walsh, 1964). A drop of the thawed suspension was added to $50 \mathrm{ml}$ of brain heart infusion broth (Difco) and incubated overnight at $37^{\circ} \mathrm{C}$. The growth was sedimented by centrifugation at $3000 \mathrm{~g}$ for $15 \mathrm{~min}$. and resuspended in such a volume of 0.85 per cent. $\mathrm{NaCl}$ that the extinction of a 1 in 10 dilution of the suspension measured at $625 \mathrm{~nm}$ was 0.39 per $\mathrm{cm}$. Albino mice of either sex, weighing $24-30 \mathrm{~g}$, were infected by the injection of $0.25 \mathrm{ml}$ of the bacterial suspension, containing $2 \times 10^{8}$ enterococci, into a tail vein.

\section{Therapeutic regimes}

Twenty-four hours after infection, the mice were started on treatment with ampicillin $200 \mathrm{mg}$ per $\mathrm{kg}$ body weight given three times daily by subcutaneous injection. This regime

Received 20 May 1969; accepted 20 Oct. 1969.

J. MED. MICROBIOL.-VOL. 3 (1970) 
maintained inhibitory concentrations of antibiotic in the kidneys for a total time of $7.5 \mathrm{hr}$ in each day. A group of mice that were immunosuppressed with cortisone acetate, $1 \mathrm{mg}$ given twice a day by subcutaneous injection, were treated by continuous intravenous infusion of ampicillin by the technique of Bainbridge and Wright (1965); Watson-Marlow ten-channel delta pumps were used to deliver $0.1 \mathrm{ml}$ per hr of a $5 \mathrm{mg}$ per ml solution of ampicillin sodium from reservoirs kept at $0^{\circ} \mathrm{C}$ in flake ice.

\section{Culture media}

L-form agar no. 1 consisted of: Brain Heart Infusion broth (Difco) $37 \mathrm{~g}$, Oxoid Ionagar no. $2,10 \mathrm{~g}$, distilled water $900 \mathrm{ml}$, and $\mathrm{NaCl} 25 \mathrm{~g}$; the $\mathrm{NaCl}$ content increased the osmolality of the medium to 1 osmole per $\mathrm{kg}$. Ten per cent. sterile horse serum and 0.0025 per cent. triphenyltetrazolium chloride (TTC, BDH) were added before the medium was poured in plates. Respiring bacteria reduce TTC to a red insoluble product (Wundt, 1950), so that respiring L-form colonies may readily be distinguished from non-viable cellular debris (Gutman et al., 1965).

L-form agar no. 2 was a modification of the medium described by Gutman et al.: Tryptone Soya Broth (Oxoid) was substituted for Phytone (BBL) and the sucrose concentration was increased from 10 to 30 per cent. (w/v).

$L$-form broth was the no. 2 medium without the agar.

\section{Detection of enterococci damaged by penicillin in the mouse kidneys}

After removal the kidneys were placed in a sterile petri dish and divided into halves. One half of each kidney was dropped into a weighed Griffiths grinding tube containing $2 \mathrm{ml}$ of $0 \cdot 3 \mathrm{M}$ sucrose in brain heart infusion broth and was homogenised after determination of its weight. One $\mathrm{ml}$ of the homogenate and three sequential ten-fold dilutions in sucrose broth were incorporated into pour plates of Oxoid no. 2 Blood Agar Base containing 0.3M sucrose. The other half of the kidney was processed in distilled water and cultured on the standard agar base. Viable counts were performed after 2 days' incubation.

This technique, devised by Guze and Kalmanson, is based on the assumption that if more bacteria are recovered on the medium containing sucrose than on the unprotected medium, the difference in counts represents penicillin-damaged, osmotically fragile enterococci that revert to the parent organism on culture in vitro. Because, however, Guze and Kalmanson's method would not detect such enterococci as were damaged by penicillin in the mouse kidney and rendered capable of growing in vitro only in the L-form, the method was modified to allow observation of these forms.

To avoid sampling errors due to an irregular distribution of renal lesions both kidneys were finely minced with a sterile scalpel. Half the renal tissue was then homogenised in 0.5M sucrose broth with a Teflon grinder (Pierce, Dubos and Schaefer, 1953), and serial ten-fold dilutions were prepared in sucrose broth; the other half was processed and diluted in distilled water. These manipulations and the preparation of the media were carried out in an enclosed cabinet under ultraviolet radiation. This irradiation reduced airborne contamination without affecting the growth of L-form cultures added to the kidneys before processing. The radiation was switched off before $0.1 \mathrm{ml}$ volumes of the dilutions of renal tissue in sucrose broth were spread on plates of L-form medium no. 1. The renal tissue processed in distilled water was cultured on brain heart infusion serum agar isotonic with plasma.

The plates were enclosed in plastic bags to reduce evaporation and were incubated in air at $37^{\circ} \mathrm{C}$. The numbers of typical colonies of enterococci were counted after incubation for $48 \mathrm{hr}$ and the cultures were examined repeatedly with a plate microscope before being discarded after 14 days.

In some experiments the remainder of the homogenate was diluted with $3 \mathrm{ml}$ of L-form broth and, after cellular debris had been deposited by centrifugation at $500 \mathrm{~g}$ for $15 \mathrm{~min}$., was filtered through an $0.45 \mu \mathrm{m}$ membrane (Millipore Ltd) into a sterile bottle. The pore size of this membrane permits the passage of some L-forms while retaining the bacterial 
forms (Klieneberger-Nobel, 1949). Bottles were examined twice weekly and subcultured into L-form broth after 7 days and on to L-form agar prior to being discarded at $4 \mathrm{wk}$.

\section{RESULTS}

Pyelonephritis was established in 75 mice and, beginning $24 \mathrm{hr}$ after infection, the animals were treated with ampicillin $200 \mathrm{mg}$ per $\mathrm{kg}$ body weight given

TABLE I

The number of viable enterococci recovered on isotonic or sucrose agar from the kidneys of mice with strain-B enterococcal pyelonephritis treated with ampicillin from the 2 nd day after infection; cortisone was used in an attempt to recall the infection

\begin{tabular}{|c|c|c|c|c|c|}
\hline \multicolumn{6}{|c|}{$\begin{array}{l}\log _{10} \text { number of viable organisms per half kidney recovered from each of } \\
25 \text { mice, in which treatment with ampicillin* had been discontinued for }\end{array}$} \\
\hline \multirow{2}{*}{\multicolumn{2}{|c|}{$12 \mathrm{hr}$, on }} & \multicolumn{4}{|c|}{14 days, during which } \\
\hline & & \multicolumn{2}{|c|}{$\begin{array}{l}\text { they were not given } \\
\text { cortisone (controls), on }\end{array}$} & \multicolumn{2}{|c|}{$\begin{array}{l}\text { they were given cortisone, } \\
\text { on }\end{array}$} \\
\hline $\begin{array}{l}\text { isotonic } \\
\text { agar } \\
\text { medium }\end{array}$ & $\begin{array}{c}\text { agar medium } \\
+0 \cdot 3 \mathrm{M} \\
\text { sucrose }\end{array}$ & $\begin{array}{l}\text { isotonic } \\
\text { agar } \\
\text { medium }\end{array}$ & $\begin{array}{c}\text { agar medium } \\
+0 \cdot 3 \mathrm{M} \\
\text { sucrose }\end{array}$ & $\begin{array}{l}\text { isotonic } \\
\text { agar } \\
\text { medium }\end{array}$ & $\begin{array}{c}\text { agar medium } \\
+0.3 \mathrm{M} \\
\text { sucrose }\end{array}$ \\
\hline $\begin{array}{c}4.12 \\
3.56 \\
2.24 \\
1.08 \\
1.96 \\
0.60 \\
<0.30 \dagger\end{array}$ & $\begin{array}{c}4.50 \\
3.38 \\
1.28 \\
0.89 \\
0.79 \\
1.30 \\
<0.30 \dagger\end{array}$ & $\begin{array}{c}3.79 \\
1.18 \\
3.56 \\
0.95 \\
0.84 \\
<0.30 \\
<0.30 \dagger\end{array}$ & $\begin{array}{c}4.08 \\
2.18 \\
2.38 \\
1.33 \\
0.76 \\
<0.30 \\
<0.30 \dagger\end{array}$ & $\begin{array}{c}4.20 \\
3.29 \\
2.71 \\
2.09 \\
0.86 \\
<0.30 \\
<0.30 \dagger\end{array}$ & $\begin{aligned} 6.20 \\
3.68 \\
2.05 \\
2.83 \\
<0.30 \\
<0.30 \\
<0.30 \dagger\end{aligned}$ \\
\hline
\end{tabular}

* Treatment with ampicillin $200 \mathrm{mg}$ per $\mathrm{kg}$ body weight was given three times daily by subcutaneous injection starting $24 \mathrm{hr}$ after the injection of $2 \times 10^{8}$ enterococci. This regimen maintained inhibitory concentrations of antibiotic in the kidneys for $7.5 \mathrm{hr}$ a day and was continued for $3 \mathrm{wk}$.

$\dagger$ The remaining 18 mice in each group yielded negative cultures on both media.

The difference between the number of enterococci recovered on sucrose agar and on isotonic agar is not statistically significant: $\mathrm{t}=0 \cdot 158$, d.f. $=15,0 \cdot 9>\mathbf{P}>0 \cdot 8$.

subcutaneously thrice a day for $3 \mathrm{wk}$. After $12 \mathrm{hr}$ had been allowed for the elimination of the antibiotic, 25 mice were killed and their kidneys were cultured by the method of Guze and Kalmanson. In an attempt to recall the infection by lowering host immunity, 25 of the remaining mice were given cortisone acetate $1 \mathrm{mg}$ by subcutaneous injection twice a day for 14 days. The final 25 mice served as controls with an unsuppressed immune response. The animals were then killed and their kidneys cultured. None of the three groups of mice yielded significantly larger numbers of organisms in the cultures grown on sucrose agar than in those grown on isotonic agar (table I) and it is concluded that no substantial number of osmotically fragile enterococci were present in the kidneys after the treatment with ampicillin. Immunosuppression with cortisone, moreover, failed to recall the infection. 
It was thought that, if after penicillin therapy only a small percentage of the enterococci present in the kidney at the start of therapy persist as osmotically fragile forms, these variants might be more readily detected by delaying treatment until the renal bacterial population was maximal. Eighty mice were therefore left 4 days to develop pyelonephritis before the treatment with ampicillin was begun, and 60 of them were killed in three groups of 20 after the treatment had been continued for 2, 3 and $4 \mathrm{wk}$. The remaining 20 animals were treated for $3 \mathrm{wk}$ and then given cortisone acetate $1 \mathrm{mg}$ twice daily for $2 \mathrm{wk}$ in an attempt to recall the infection. After the animals had been killed, their kidneys were cultured by the modified Guze-Kalmanson technique and the bladder urine was plated directly on to L-form agar no. 1. Organisms growing as typical enterococcal colonies on L-form agar no. 1 and on isotonic serum agar were counted after incubation for $48 \mathrm{hr}$. In the group of 20 mice treated with ampicillin for 14 days, enterococci were recovered from the kidneys of 16 animals and the average $\log _{10}$ count per kidney was 1.76 on L-form agar no. 1 and 1.84 on isotonic serum agar. In the 20 mice treated for 21 days, enterococci were recovered from the kidneys of 13 animals and the average counts were 1.24 on L-form agar and 1.26 on isotonic serum agar. After 28 days' treatment, enterococci were recovered from the kidneys of 11 out of 20 mice and the average counts were 0.81 on L-form agar and 0.75 on isotonic serum agar. Despite continued incubation of the cultures for up to 14 days, no new colonies of enterococci appeared in addition to those present at 2 days, and no structures resembling L-form colonies were observed. Of the 20 mice treated with cortisone in an attempt to recall the infection, 6 died of intercurrent infection, but the kidneys of 6 of the survivors yielded no growth either on L-form agar no. 1 or on isotonic serum agar. Thus no penicillin-damaged enterococci capable either of reverting to the parent coccal form in vitro or of growing as an L-form were detected in these kidneys.

This failure to demonstrate surviving organisms might be explained by the mechanical destruction of penicillin-damaged enterococci during the homogenisation of the kidney tissue, yet when $10^{4} \mathrm{~L}$-forms induced in vitro were added to three tubes of tissue before processing, the viable count was not reduced by homogenisation. Even if enterococci damaged by penicillin in vivo are more fragile than L-forms grown in vitro it would be reasonable to expect that penicillin-damaged bacteria would be excreted in the urine if large numbers of them persisted in the renal medulla. Although a few enterococci, $<10^{3}$ per $\mathrm{ml}$, were recovered from the urine from 12 out of 80 mice, L-form colonies were not detected and fresh enterococcal colonies did not appear after the first 2 days of incubation.

\section{Infection with different strains of enterococci}

Four groups of mice were infected with enterococci of strains $M, R, T$ and $Y$, and 4 days later the animals were treated with ampicillin for $3 \mathrm{wk}$. The mice were then killed and their kidneys cultured by the modified Guze-Kalmanson technique. The average $\log _{10}$ numbers of enterococci per kidney recovered 
from the mice infected with the different strains were: strain M, 1.54 on L-form agar no. 1 and 1.46 on isotonic agar; strain $\mathrm{R}, 2.25$ on L-form agar no. 1 and 2.25 on isotonic agar; strain $\mathrm{T}, 0.42$ on L-form agar no. 1 and 0.40 on isotonic agar; strain $Y, 1.92$ on L-form agar no. 1 and 1.84 on isotonic agar. Cultures of both kidneys and of urine were incubated for a period of $2 \mathrm{wk}$, but no new colonies of enterococci appeared after the first $48 \mathrm{hr}$ and no bodies resembling L-form colonies were observed. The failure of penicillin-damaged, osmotically fragile forms to persist in the kidneys is therefore not unique to strain B enterococci, although it remains possible that some strains capable of producing such variants do exist.

\section{Persistence of enterococci in mice treated with cortisone}

Since it seemed possible that enterococcal L-forms induced in pyelonephritic kidneys by therapy with penicillin might be destroyed by the immune mechanisms of the host, it was considered important to determine whether osmotically fragile organisms could be detected when the renal defence systems were suppressed. The treatment of pyelonephritic mice with cortisone acetate $1 \mathrm{mg}$ twice daily led to the uncontrolled multiplication of enterococci in the kidneys and histological examination 5 days after challenge showed massive bacterial invasion with papillary necrosis and a relatively poor cellular response. In immunologically normal animals the infection remained localised, and there were fewer bacteria and a marked inflammatory response. Intermittent chemotherapy failed to control the enterococcal pyelonephritis in cortisone-treated animals. Groups of 20 mice receiving cortisone were therefore treated by the continuous intravenous infusion of a solution of ampicillin, $5 \mathrm{mg}$ per $\mathrm{ml}$, at the rate of $0.1 \mathrm{ml}$ per $\mathrm{hr}$ beginning $36 \mathrm{hr}$ after challenge. This therapy maintained ampicillin levels of 8-20 $\mu \mathrm{g}$ per $\mathrm{ml}$ in the blood, and levels of $100-300 \mu \mathrm{g}$ per $\mathrm{g}$ in the kidney. Eighteen out of 100 mice were satisfactorily perfused for $2 \mathrm{wk}$, and after allowing $12 \mathrm{hr}$ for clearance of the antibiotic these animals were killed and their kidneys cultured.

To reduce possible mechanical rupture of L-forms during processing, one of each pair of kidneys was finely minced and gently homogenised in sucrose broth with a Griffiths grinder before it was inoculated on plates of the two L-form media and brain heart infusion serum agar. Although the bacteria were not subjected to osmotic shock in distilled water, the viable count on isotonic medium was equal to that on the two L-form media (table II). Cultures from urine and kidney on both L-form media were examined repeatedly for $4 \mathrm{wk}$, but no bodies resembling L-form colonies were observed. The remaining homogenates were used for enrichment culture in L-form broth after removal of bacterial forms by membrane filtration. Four cultures were contaminated but, despite incubation for $4 \mathrm{wk}$ and subculture into fresh media, no L-forms were recovered from the other cultures. The renal papilla from the opposite kidney was cultured in L-form broth, but heavy growths of enterococci were present in all bottles after incubation for $48 \mathrm{hr}$. 


\section{DISCUSSION}

The principle that bacteria with a damaged or absent cell wall would be destroyed if subjected to osmotic shock in distilled water, but could survive and multiply on osmotically protected media, was used in an attempt to detect enterococci damaged by penicillin in experimentally infected mouse kidneys.

\section{TABLE II}

The effect of treatment with cortisone on the formation of osmotically fragile variants of enterococcus strain B in the pyelonephritic kidneys of 18 mice continuously infused with ampicillin for $2 w^{*}$

\begin{tabular}{|c|c|c|}
\hline isotonic agar & L-form agar no. 1 & L-form agar no. 2 \\
\hline $\begin{array}{r}2.95 \\
2.95 \\
2.43 \\
2.09 \\
1.93 \\
1.78 \\
1.72 \\
1.76 \\
2.48 \\
1.08 \\
1.40 \\
0.95 \\
0.70 \\
0.70 \\
0.85 \\
0.30 \\
<0.00 \\
<0.00\end{array}$ & $\begin{array}{r}2.84 \\
2.91 \\
2.26 \\
2.00 \\
1.89 \\
1.84 \\
1.74 \\
1.80 \\
2.52 \\
1.41 \\
1.52 \\
0.85 \\
0.30 \\
0.48 \\
0.60 \\
0.48 \\
0.30 \\
<0.00\end{array}$ & $\begin{array}{r}2.62 \\
2.70 \\
2.15 \\
2.20 \\
2.80 \\
2.08 \\
1.79 \\
1.91 \\
2.62 \\
1.22 \\
1.28 \\
1.08 \\
0.78 \\
0.60 \\
0.95 \\
<0.00 \\
0.48 \\
<0.00\end{array}$ \\
\hline Mean & 1.43 & $1.52 \dagger$ \\
\hline
\end{tabular}

* Intravenous infusion with ampicillin to maintain a level between 8 and $20 \mu \mathrm{g}$ per $\mathrm{ml}$ in blood was begun $36 \mathrm{hr}$ after intravenous inoculation of $2 \times 10^{8}$ enterococci and was continued for $2 \mathrm{wk}$. Mice were killed for examination $12 \mathrm{hr}$ after the infusion had been ended.

$\dagger$ The difference between the number of enterococci recovered on L-form agar no. 2 and on isotonic agar is not statistically significant: $\mathbf{t}=0.79$, d.f. $=17,0.5>\mathbf{P}>0.4$.

The failure to recover such variants, or enterococcal L-forms, from the kidneys of pyelonephritic mice treated with ampicillin contrasts with the reported persistence of " protoplast" forms after treatment of enterococcal pyelonephritis in rats with penicillin (Guze and Kalmanson, 1964). It is likely that the techniques used to culture the mouse kidneys would have detected any L-forms present, since the media supported L-form growth in vitro. L-forms added to the kidneys were recovered after processing of the tissue. Moreover, destruction during homogenisation could not explain my failure to recover variants from urine plated directly on to L-form agar. A possible explanation was that 
penicillin-damaged enterococci are destroyed by the renal defence systems in the mouse though not by those in the rat, but such a difference is unlikely because no L-forms were detected in the kidneys of mice after immunosuppression with cortisone. Again, rat serum contains natural antibodies capable of killing enterococcal L-forms (Kalmanson et al., 1966), but L-forms survive in osmotically protected mouse serum (Watt, 1970). This suggests that the failure to induce L-forms in the mouse was due to inimical physiological conditions in the kidney.

Mice excrete a highly concentrated urine with an average osmolality of 2.6 osmoles per $\mathrm{kg}$ (Silverstein, 1961), yet the survival of enterococcal L-forms in mouse urine was improved by the addition of molar sucrose, presumably because urea cannot act as an osmotic stabiliser (Watt, 1970). Although osmotic fragility could explain the failure to recover L-forms from the mouse kidneys, there is no evidence to suggest that the rat model would favour the survival of osmotically fragile variants. "Protoplasts" of the Guze-Kalmanson strain of enterococcus require an osmotic protection of 1200 m.osmoles per $\mathrm{kg}$ for optimal survival in vitro (Montgomerie, Kalmanson and Guze, 1967), but the renal medullary osmolality in the rat rarely exceeds $700-800$ m.osmoles per $\mathrm{kg}$ (Kass, 1968). Nevertheless, bacteria transformed into L-forms in the host might be less fragile than variants grown in vitro, as is suggested by the observation that L-forms of Staphylococcus aureus were slowly destroyed in rabbit urine, but could be recovered from the kidneys of rabbits with staphylococcal pyelonephritis after treatment with methicillin (Young and Dahlquist, 1967).

If the increased numbers of bacteria recovered by Guze and Kalmanson from rat kidneys cultured on media containing $0 \cdot 3 \mathrm{M}$ sucrose represented penicillin-damaged, osmotically fragile enterococci, it is difficult to understand why these "protoplasts" survived hypotonic conditions in the renal medulla during osmotic diuresis yet were destroyed in physiological saline on isolation from the kidney (Guze and Kalmanson; Kalmanson and Guze, 1964). A further problem is to explain why " protoplasts" persisted in the kidneys at least $13 \mathrm{wk}$ after penicillin therapy was discontinued, but immediately reverted to typical enterococci in vitro. Kalmanson and Guze suggest that antibodies formed against the cell-wall prevented its re-synthesis. One might expect that the natural antibodies that destroy enterococcal " protoplasts" in vitro (Kalmanson et al.) would also be effective in the kidney.

The simplest explanation of Guze and Kalmanson's findings would be that the enterococci they recovered were not variants lacking cell-walls. Eastridge and Farrar (1968) appear to have confirmed the Guze-Kalmanson experiments, yet when the $t$ test was applied to the difference between the number of enterococci recovered on hypertonic medium and the number recovered on standard medium, even from untreated control rats, the count was significantly higher on the hypertonic medium: $t=3.61$, d.f. $=6 ; 0.02>\mathrm{P}>0.01$. Therefore, it is difficult to accept that the difference in counts by the two methods represents the number of penicillin-damaged, osmotically fragile enterococci in the kidneys. 


\section{SUMMARY}

Despite repeated attempts, and the use of a variety of cultural methods, no osmotically fragile persisting organisms, or L-forms, could be detected in the kidneys of mice with enterococcal pyelonephritis after they had been treated with ampicillin. L-forms added to the kidneys were readily recovered after processing of the tissue in a Teflon grinder, and destruction during processing could not explain the failure to detect variants in urine plated directly on to L-form agar. No L-forms were detected in the kidneys after suppression of renal defence systems with cortisone. It is suggested that the failure of penicillin-damaged enterococci to grow as L-forms was due to inimical physiological conditions in the mouse kidney.

I am indebted to Professor R. E. O. Williams for his advice and encouragement and to Dr N. A. Mitchison for loan of the equipment used in the intravenous perfusion of mice.

\section{REFERENCES}

Baingridge, D. R., AND Wright, B. M. 1965. J. Physiol., Lond., 177, 6P.

Eastridge, R. R., ANd Farrar, W. E. . 1968. Proc. Soc. Exp. Biol. Med., 128, 1193.

Gore, L. F., AND WALSh, P. . . . 1964. J. Med. Lab. Tech., 21, 244.

Gutman, L. T., Turck, M.. Petersdorf, 1965. J. Clin. Invest., 44, 1945.

R. G., AND WEDGEWOOD, R. J.

Guze, L. B., and Kalmanson, G. M. . 1964. Science, N.Y., 143, 1340.

Kalmanson, G. M., and Guze, L. B. . 1964. J. Amer. Med. Assoc., 190, 1107.

Kalmanson, G. M., Hubert, E. G., 1966. In Antimicrobial agents and chemoMontgomerie, J. Z., AND Guze, L. B. therapy, 1965, ed. by Gladys L. Hobby,

Kass, E. H.

1968. In Microbial protoplasts, spheroplastsand L-forms, ed. by L. B. Guze, Baltimore, p. 498.

Klieneberger-Nobel, Emmy . . . . . 1949. J. Hyg., Camb., 47, 393.

Montgomerie, J. Z., Kalmanson, G. M., 1967. J. Lab. Clin. Med., 70, 539. AND GUZE, L. B.

Pierce, Cynthia H., Dubos, R. J., AND 1953. J. Exp. Med., 97, 189. SCHAEFER, W. B.

Silverstein, E. . . . . . . . . 1961. J. Appl. Physiol., 16, 194.

WATT, P. J. . . . . . . . . . 1969. M.D. Thesis, Univ. London.

W"

WUNDT, W. . . . . . . . . . . . . 1950. Dt. med. Wschr., 75, 1471.

Young, R. M., and Dahlquist, E. H. . 1967. Amer. J. Clin. Path., 48, 466. 